\title{
ANALIZA WIĘZÓW MANIPULATORA W ZADANIU ZROBOTYZOWANEJ OBRÓBKI MECHANICZNEJ DYFUZORA
}

\begin{abstract}
Artykuł dotyczy analizy więzów geometrycznych narzuconych na końcówkę roboczą robota manipulacyjnego, którego zadaniem jest realizacja obróbki mechanicznej dyfuzora. $\mathrm{Z}$ punktu widzenia teorii sterowania, realizacja omawianego zadania jest traktowana jako sterowanie obiektem z ograniczeniami ruchu. Wymaga to określenia zadanej trajektorii układu sterowania robota rozumianej jako trajektoria pozycyjna oraz siłowa. W pracy zaprezentowano geometrię dyfuzora wraz z opisem matematycznym krawędzi, która ma zostać zatępiona. Podano zestaw więzów naturalnych i sztucznych, pozycyjnych i siłowych dla tego zadania oraz dla zadania wiercenia otworów. Podano sposób wyznaczania trajektorii pozycyjnej i siłowej, która będzie stanowić trajektorię zadaną układu sterowania robota. Zaprezentowano wyniki symulacji generowania trajektorii ruchu końcówki roboczej.
\end{abstract}

Słowa kluczowe: więzy geometryczne, robot manipulacyjny, planowanie trajektorii, zrobotyzowana obróbka

\section{Wprowadzenie}

Poprawna realizacja obróbki mechanicznej elementów części maszyn i urządzeń wymaga zastosowania precyzyjnych stanowisk obróbczych, najczęściej maszyn CNC. Specyfika niektórych zadań obróbki, związana z niepewnością położenia oraz kształtu obrabianej powierzchni czy krawędzi powoduje, że niektóre operacje są często wykonywane ręcznie na stanowiskach ślusarskich czy wiertarskich. Automatyzacja takich operacji jest możliwa, wymaga jednak zastosowania złożonych systemów, których istotną cechą jest programowalność i elastyczność [2]. W skład takich systemów wchodzą przede wszystkim roboty z odpowiednimi narzędziami do obróbki mechanicznej oraz inne urządzenia pomocnicze takie jak pozycjonery, transportery i systemy wizyjne [3].

Takie systemy umożliwiają zaprogramowanie i realizację procesów ob-

\footnotetext{
${ }^{1}$ Autor do korespondencji/corresponding author: Piotr Gierlak, Politechnika Rzeszowska, al. Powstańców Warszawy 12, 35-959 Rzeszów, tel.: (17) 8651854, e-mail: pgierlak@ prz.edu.pl
} 
róbki mechanicznej elementów, których kształt i położenie są zmienne w określonych granicach. Przykładem jest zadanie obróbki mechanicznej dyfuzora silnika (rys. 1). Losowa zmienność kształtu i położenia dyfuzora, który jest elementem odlewu, wynika m.in. ze zjawiska skurczu występującego podczas krzepnięcia oraz niedokładności wykonania formy odlewniczej.

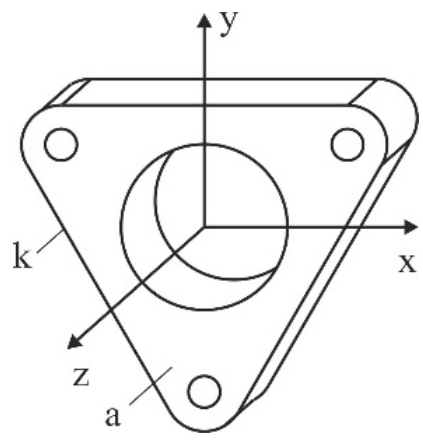

Rys. 1. Kształt dyfuzora

Fig. 1. The shape of the diffuser

Płaszczyzna $a$ dyfuzora jest obrobiona przez frezowanie, natomiast krawędź $k$ należy zatępić. Ponadto należy wykonać otwory przelotowe o osiach prostopadłych do płaszczyzny $a$.

Ważnym aspektem praktycznym jest wybór sposobu realizacji omówionych zadań. Do realizacji procesu obróbki krawędzi dyfuzora w praktyce można stosować co najmniej dwie strategie sterowania. Pierwsza z nich polega na zastosowaniu tzw. hybrydowego sterowania pozycyjno-siłowego. Hybrydowy sterownik pozycyjno-siłowy $[4,12]$ powinien umożliwiać:

- sterowanie pozycją końcówki manipulatora wzdłuż kierunków, na których istnieją naturalne więzy siłowe,

- sterowanie siłami wywieranymi przez końcówkę manipulatora wzdłuż kierunków, na których istnieją naturalne więzy pozycyjne,

- realizację dowolnej kombinacji powyższych zadań wzdłuż ortogonalnych kierunków układu więzów $\{c\}$.

Zastosowanie takiej strategii wymaga wyposażenia robota w pakiet sprzętowo-programowy, w skład którego musi wchodzić układ umożliwiający wyznaczenie sił i momentów w końcówce roboczej manipulatora. Można zastosować np. czujnik sił i momentów umieszczony w końcówce robota [2] lub układ pomiaru obciążenia napędów robota [18]. Dodatkowo rozbudowany musi zostać układ sterowania robota w celu realizacji pętli sterowania siłami. Schemat układu sterowania pozycyjno-siłowego umożliwiającego realizację omawianego zadania przedstawiono na rys. 2. 


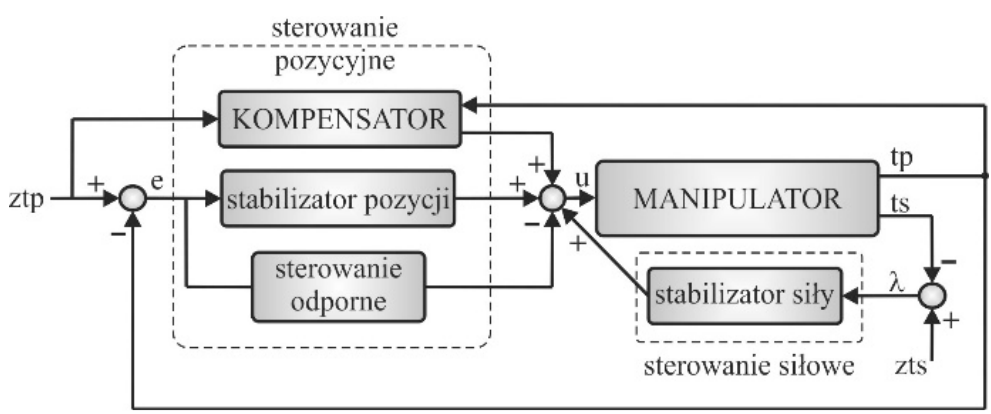

Rys. 2. Schemat układu sterowania pozycyjno-siłowego: ztp - zadana trajektoria pozycyjna, tp - trajektoria pozycyjna, e - błąd realizacji trajektorii pozycyjnej, zts - zadana trajektoria siłowa, ts - trajektoria siłowa, $\lambda$ - błąd realizacji trajektorii siłowej, $\mathrm{u}$ - sterowanie

Fig. 2. The scheme of the position/force control system: ztp - desired positional trajectory, tp - positional trajectory, e - error of position, zts - desired force trajectory, ts - force trajectory, $\lambda$ - error of force, $\mathrm{u}$ - control input

Struktura sterowania pozycyjnego jest typowa dla układów sterowania współczesnych robotów, w których problem nadążania za zadaną trajektorią ruchu jest definiowany jako zadanie stabilizacji błędu nadążania. Rolą kompensatora jest kompensowanie nieliniowości sterowanego obiektu, natomiast rolą stabilizatora jest eliminowanie błędu nadążania wynikającego z niedokładnej kompensacji nieliniowości. Dodatkowo wprowadza się człon zapewniający odporność na zakłócenia nazywany sterowaniem odpornym, a jego struktura zależy m.in. od struktury kompensatora i sposobu analizy stabilności układu. Typowym rozwiązaniem stosowanym w pętli sterowania siłowego jest zastosowanie stabilizatora siły, którego celem jest eliminowanie błędu trajektorii siłowej. Szczegółowe opracowania dotyczące rozwiązań stosowanych w układach sterowania pozycyjno-siłowego zostały przedstawione w pracach autora. Analizowano w nich m.in. zastosowanie metod klasycznych, układów neuronowych i neuronowo-rozmytych w sterowaniu pozycyjnym $[6,7,9,10]$ oraz regulatorów konwencjonalnych (PID) i rozmytych w sterowaniu siłowym [11]. Inne rozwiązania sterowania siłowego przedstawione są w pracach [15, 16].

Alternatywnym i tańszym rozwiązaniem, nie wymagającym stosowania układu sterowania siłowego, jest wyposażenie robota manipulacyjnego w tzw. podatne narzędzie [2]. Jest ono tak skonstruowane, że wrzeciono, w którym zamocowane jest narzędzie skrawające, ma możliwość odchylania się od położenia neutralnego. Dostępne na rynku tego typu rozwiązania to np. narzędzia: FDB firmy Schunk [20] oraz DT-A390 firmy RAD [19]. Istota tych rozwiązań polega na sterowaniu podatnością wrzeciona poprzez zmianę ciśnienia powietrza doprowadzanego do narzędzia. Przy większym ciśnieniu powietrza siła wymagana do wychylenia wrzeciona jest większa. Układ taki nie umożliwia 
sterowania siłami interakcji $\mathrm{w}$ torze zamkniętym - stosowane jest tu jedynie sterowanie typu pozycyjnego - a siła interakcji jest dobierana w sposób przybliżony i zależy od aktualnej wartości ciśnienia doprowadzanego do układu sterowania podatnością. Dodatkową korzyścią z zastosowania podatnego narzędzia jest zabezpieczenie robota i obrabianego przedmiotu przed uszkodzeniem w wyniku wygenerowania zbyt dużych sił lub momentów sił.

Obydwie przedstawione strategie sterowania zapewniają kontakt narzędzia z obrabianym przedmiotem nawet wówczas, gdy jego kształt i położenie odbiegają od nominalnych wartości. Jest to efektem uwzględniania w procesie sterowania siły interakcji robota $\mathrm{z}$ otoczeniem.

Do wykonania przedstawionych zadań zastosowany zostanie manipulator kartezjański własnej konstrukcji posiadający trzy stopnie swobody [8]. Jest to manipulator przeznaczony do realizacji badań dotyczących m.in. robotyzacji procesów obróbki mechanicznej. Umożliwia on realizowanie dwóch niezależnych translacji końcówki w płaszczyźnie poziomej i jednej w kierunku pionowym. Wyposażony jest w moduły liniowe, w skład których wchodzą prowadnice $\mathrm{z}$ wózkami napędzanymi przez silniki prądu stałego za pośrednictwem przekładni zębatych oraz śrub kulowych. W celu umożliwienia realizacji pętli sterowania pozycyjnego manipulator wyposażono w enkodery zamocowane na wałach silników napędowych. Aby umożliwić realizację pętli sterowania siłowego, koniecznej do sterowania siłami interakcji robota z otoczeniem, w końcówce roboczej umieszczono czujnik siły FTD-Gamma SI-130-10 firmy ATI [17]. Jest to czujnik umożliwiający pomiar trzech składowych siły i trzech składowych momentu siły w końcówce roboczej. Do czujnika siły mocowana jest głowica, w której znajduje się narzędzie skrawające, np. pilnik, frez itp.

$\mathrm{Z}$ punktu widzenia teorii sterowania robotami, realizacja omawianego zadania jest traktowana jako sterowanie obiektem z częściowymi ograniczeniami ruchu, co prowadzi do sterowania typu pozycyjno-siłowego [16]. Wymaga to określenia zadanej trajektorii układu sterowania robota rozumianej jako trajektoria pozycyjna oraz trajektoria siłowa. Problem ten zostanie wyjaśniony w kolejnych rozdziałach artykułu

$\mathrm{W}$ rozdziale 2 przedstawiono więzy manipulatora wynikające $\mathrm{z}$ zadania obróbki krawędzi dyfuzora. W rozdziale 3 wyznaczono trajektorię pozycyjnosiłową zgodną z więzami manipulatora. Rozdział 4 dotyczy analizy więzów manipulatora wynikających $\mathrm{z}$ zadania wiercenia otworów $\mathrm{w}$ dyfuzorze. $\mathrm{W}$ ostatnim rozdziale dokonano podsumowania pracy.

\section{Więzy manipulatora w zadaniu obróbki krawędzi dyfuzora}

Dla każdego zadania można określić tzw. uogólnioną powierzchnię $\mathrm{z}$ więzami pozycyjnymi na kierunkach normalnych do tej powierzchni i więzami siłowymi na kierunkach do niej stycznych $[5,13]$. Pojęcie więzów pozycyjnych odnosi się do więzów narzuconych na pozycję i orientację końcówki 
roboczej manipulatora, natomiast pojęcie więzów siłowych odnosi się do więzów narzuconych na siły i momenty interakcji końcówki z obrabianym przedmiotem. Więzy te rozdzielają dopuszczalne ruchy końcówki manipulatora na dwa ortogonalne zbiory, a ruchy te muszą być sterowane wg odmiennych kryteriów.

Na rys. 3 określono zestaw więzów naturalnych i sztucznych, pozycyjnych oraz siłowych dla przypadku obróbki krawędzi dyfuzora za pomocą pilnika zamocowanego w końcówce manipulatora w przypadku dokładnie znanej geometrii krawędzi $k$.

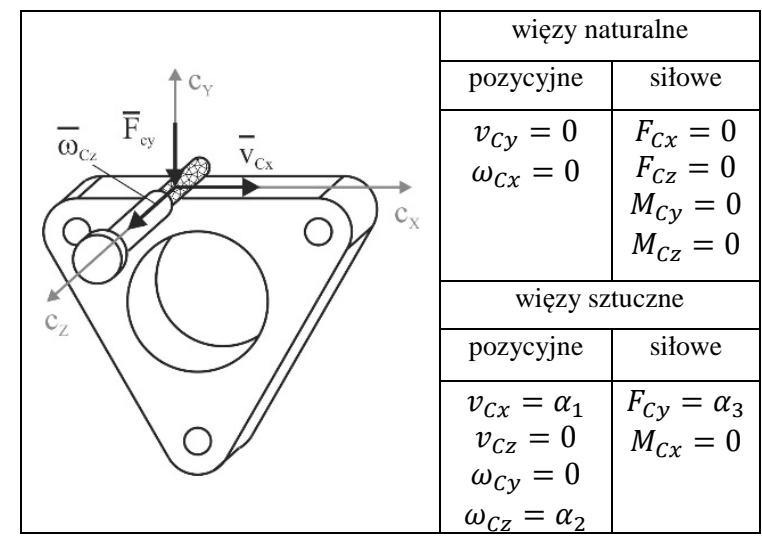

Rys. 3. Więzy naturalne i sztuczne w zadaniu obróbki krawędzi dyfuzora silnika

Fig. 3. Natural and artificial constraints in the task of machining of the engine diffuser edge

Zadanie określono względem układu więzów $\{c\}$, który jest związany $\mathrm{z}$ uchwytem narzędzia i porusza się wraz z nim. Obok rysunku podano więzy naturalne dla rozważanego zadania. Zostanie teraz wyjaśniony sens tych więzów. Ruch narzędzia przez powierzchnię nie jest możliwy czyli ograniczona jest translacja wzdłuż osi $c_{Y}$ oraz rotacja względem osi $c_{X}$, dlatego $v_{C y}=0$ i $\omega_{C x}=0$. Więzy pozycyjne określono tu przez podanie wartości prędkości. $\mathrm{W}$ przypadku pominięcia oporów ruchu występujących pomiędzy pilnikiem i powierzchnią dyfuzora okazuje się, że nie jest możliwe wywarcie siły na kierunkach osi $c_{X}$ i $c_{Z}$ oraz momentu względem osi $c_{Y}$ i $c_{Z}$, dlatego $F_{C x}=0, F_{C z}=0$, $M_{C y}=0$ i $M_{C Z}=0$. Jest to uproszczenie przyjęte w celu uczynienia opisu procesu obróbki bardziej przejrzystym.

Uzupełnieniem więzów naturalnych są więzy sztuczne, które powstają przez podanie żądanego ruchu końcówki lub żądanej siły wywieranej przez nią. Tak jak więzy naturalne, również więzy sztuczne określa się na kierunkach normalnych i stycznych do uogólnionej powierzchni z tą różnicą, że na kierunkach normalnych do uogólnionej powierzchni są określane sztuczne 
więzy siłowe, zaś na kierunkach stycznych są określane sztuczne więzy pozycyjne. Nie ma więc sprzeczności pomiędzy więzami naturalnymi i sztucznymi.

W czasie obróbki krawędzi końcówka musi wykonywać ruch postępowy z prędkością $\alpha_{1}$ względem osi $c_{X}$, dlatego $v_{C X}=\alpha_{1}$, natomiast ruch postępowy względem osi $c_{Z}$ jest niedopuszczalny, gdyż narzędzie nie powinno tracić kontaktu z obrabianą powierzchnią, dlatego $v_{C z}=0$. Obrót narzędzia względem osi $c_{Y}$ nie jest konieczny, dlatego $\omega_{C y}=0$. Aby obróbka była możliwa narzędzie musi wykonywać obrót względem osi $c_{Z}$ z prędkością kątową $\alpha_{2}$ i być dociskane do powierzchni z odpowiednią siłą $\alpha_{3}$ na kierunku $c_{Y}$, stąd $\omega_{C z}=\alpha_{2}$ oraz $F_{C y}=\alpha_{3}$. Wywieranie momentu względem osi $c_{X}$ nie jest korzystne w rozpatrywanym procesie, dlatego $M_{C x}=0$.

W celu zaplanowania ruchu końcówki roboczej manipulatora (przyjęto, że będzie to arbitralnie wybrany punkt D) należy podać matematyczny opis kształtu obrabianej krawędzi. Będzie to równanie więzów narzuconych na ruch końcówki manipulatora. Ze względu na kształt krawędzi podzielono ją na sześć części (rys. 4), z których każda będzie opisana odrębnymi równaniami.

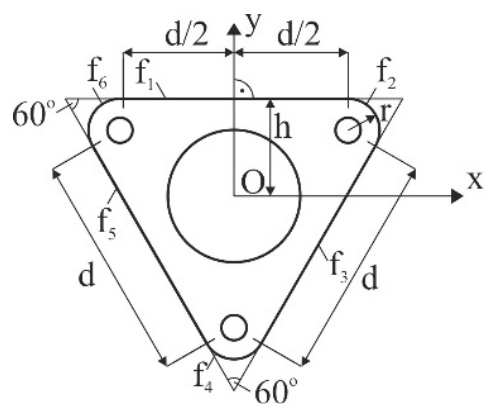

Rys. 4. Geometria dyfuzora

Fig. 4. Geometry of the diffuser

$$
\begin{aligned}
& \left\{\begin{array}{l}
f_{1}=y_{D}-h=0, \\
x_{D} \in\left\langle-\frac{d}{2}, \frac{d}{2}\right\rangle
\end{array}\right. \\
& \left\{\begin{array}{l}
f_{2}=\left(x_{D}-\frac{d}{2}\right)^{2}+\left(y_{D}-h+r\right)^{2}-r^{2}=0, \\
y_{D} \in\left\langle h, h-\frac{3}{2} r\right\rangle
\end{array}\right.
\end{aligned}
$$




$$
\begin{aligned}
& \left\{\begin{array}{l}
f_{3}=y_{D}-\sqrt{3} x_{D}+2 h=0, \\
y_{D} \in\left\langle h-\frac{3}{2} r, h-\frac{3}{2} r-\frac{\sqrt{3}}{2} d\right\rangle
\end{array}\right. \\
& \left\{\begin{array}{l}
f_{4}=x_{D}^{2}+\left(y_{D}+2 h-2 r\right)^{2}-r^{2}=0, \\
x_{D} \in\left\langle\frac{\sqrt{3}}{2} r,-\frac{\sqrt{3}}{2} r\right\rangle
\end{array}\right. \\
& \left\{\begin{array}{l}
f_{5}=y_{D}+\sqrt{3} x_{D}+2 h=0, \\
y_{D} \in\left\langle h-\frac{3}{2} r-\frac{\sqrt{3}}{2} d, h-\frac{3}{2} r\right\rangle
\end{array}\right. \\
& \left\{\begin{array}{l}
f_{6}=\left(x_{D}+\frac{d}{2}\right)^{2}+\left(y_{D}-h+r\right)^{2}-r^{2}=0, \\
y_{D} \in\left\langle h-\frac{3}{2} r, h\right\rangle
\end{array}\right.
\end{aligned}
$$

gdzie: $f_{1}, \ldots, f_{6}$ - równania więzów (krawędzi dyfuzora),

$d, h, r$-wielkości geometryczne charakteryzujące dyfuzor (rys. 3), $x_{D}, y_{D}$ - współrzędne punktu D - końcówki manipulatora.

Równania (1) - (6) to równania więzów geometrycznych skleronomicznych dwustronnych $[1,14]$ narzuconych na ruch końcówki roboczej manipulatora. Zależności (1), (3) i (5) to równania prostych, natomiast zależności (2), (4) i (6) to równania okręgów. Z powyższych wzorów wynika, że równania więzów będą się zmieniać przedziałami podczas ruchu końcówki manipulatora.

\section{Trajektoria pozycyjna i siłowa}

Do określenia trajektorii pozycyjnej końcówki roboczej (punktu D) zastosowane zostaną równania (1) - (6) interpretowane jako równania toru końcówki. Wektor prędkości punktu D w płaszczyźnie $x y$ to

$$
\mathbf{v}_{D}=\left[\begin{array}{l}
\dot{x}_{D} \\
\dot{y}_{D}
\end{array}\right]
$$

gdzie: $\mathbf{v}_{\mathrm{D}}$ - wektor prędkości punktu $\mathrm{D}$, 
$\dot{x}_{D}, \dot{y}_{D}-$ składowe prędkości punktu D.

Wartość prędkości określa wzór

$$
v_{D}=\sqrt{\dot{x}_{D}^{2}+\dot{y}_{D}^{2}}
$$

gdzie: $v_{D}$ - wartość prędkości punktu D.

Wektor prędkości musi być styczny do toru aby prędkość punktu D była możliwa do zrealizowania, muszą więc być spełnione następujące równania

$$
\left\{\begin{array}{l}
\operatorname{gradf} f_{1} \cdot \mathbf{v}_{D}=0, \\
\operatorname{gradf} f_{2} \cdot \mathbf{v}_{D}=0, \\
\vdots \\
\operatorname{gradf}_{6} \cdot \mathbf{v}_{D}=0
\end{array}\right.
$$

które po rozwinięciu będą miały postać

$$
\left\{\begin{array}{l}
f_{1 x} \dot{x}_{D}+f_{1 y} \dot{y}_{D}=0, \\
f_{2 x} \dot{x}_{D}+f_{2 y} \dot{y}_{D}=0, \\
\vdots \\
f_{6 x} \dot{x}_{D}+f_{6 y} \dot{y}_{D}=0
\end{array}\right.
$$

gdzie: $f_{i x}=\frac{\partial f_{i}}{\partial x_{D}}, f_{i y}=\frac{\partial f_{i}}{\partial y_{D}}, i=1,2, \ldots, 6$.

Rozwiązując równania (8) i (10) dla każdego z sześciu fragmentów toru otrzymano równania określające składowe prędkości punktu D w następującej formie

$$
\left\{\begin{array}{l}
\dot{x}_{D}=\mp \frac{f_{i y} v_{D}}{\sqrt{f_{i x}^{2}+f_{i y}^{2}}} \\
\dot{y}_{D}= \pm \frac{f_{i x} v_{D}}{\sqrt{f_{i x}^{2}+f_{i y}^{2}}}
\end{array}\right.
$$

W analizowanym przypadku będzie 


$$
\left\{\begin{array}{l}
f_{1 x}=0, f_{1 y}=1, \\
f_{2 x}=2\left(x_{D}-\frac{d}{2}\right), f_{2 y}=2\left(y_{D}-h+r\right), \\
f_{3 x}=-\sqrt{3}, f_{3 y}=1, \\
f_{4 x}=2 x_{D}, f_{4 y}=2\left(y_{D}+2 h-2 r\right), \\
f_{5 x}=\sqrt{3}, f_{5 y}=1, \\
f_{6 x}=2\left(x_{D}+\frac{d}{2}\right), f_{6 y}=2\left(y_{D}-h+r\right)
\end{array}\right.
$$

Układ (11) to układ równań różniczkowych, które po rozwiązaniu z warunkami początkowymi wynikającymi z przyjętego toru ruchu punktu D (rys. 5a), posłużą do wygenerowania przebiegów czasowych przemieszczeń i składowych prędkości końcówki manipulatora w płaszczyźnie $x y$. Podczas rozwiązywania układu równań (11) należy uwzględnić sześć przedziałów. Wartość prędkości punktu $\mathrm{D}$ wynika z przyjętych sztucznych więzów pozycyjnych określonych w rozdziale 2 , czyli $v_{D}=v_{C}=\alpha_{1}$. Prędkość ruchu końcówki manipulatora wynika z założeń dotyczących realizacji procesu technologicznego. Przyjmuje się profil prędkości zawierający fazę rozpędzania, ruchu ze stałą prędkością oraz fazę hamowania, który często jest profilem trapezowym. W celu zapewnienia istnienia ciągłych pochodnych funkcji prędkości, profil trapezowy aproksymowano funkcją uwzględniającą okresy przejściowe pomiędzy poszczególnymi fazami ruchu (rys. 5b), czyli

$$
v_{D}=\frac{v_{D \max }}{1+\exp \left[-c_{P}\left(t-t_{1}\right)\right]}-\frac{v_{D \max }}{1+\exp \left[-c_{P}\left(t-t_{2}\right)\right]}
$$

gdzie: $v_{D \max }=0.01 \mathrm{~m} / \mathrm{s}$ - wartość maksymalna prędkości,

$c_{P}=101 / \mathrm{s}$ - współczynnik wpływający na długość fazy rozpędzania i hamowania (zwiększenie jego wartości powoduje skrócenie tych faz), $t_{1}=5 \mathrm{~s}$ - czas, w którym $v_{D}=v_{D \max } / 2$ podczas fazy rozpędzania, $t_{2}=33 \mathrm{~s}$ - czas, w którym $v_{D}=v_{D \max } / 2$ podczas hamowania, $t \in\langle 0,40\rangle \mathrm{s}$.

W wyniku numerycznego rozwiązania równan (11) uzyskano trajektorię pozycyjną przedstawioną na rys. 6 . 

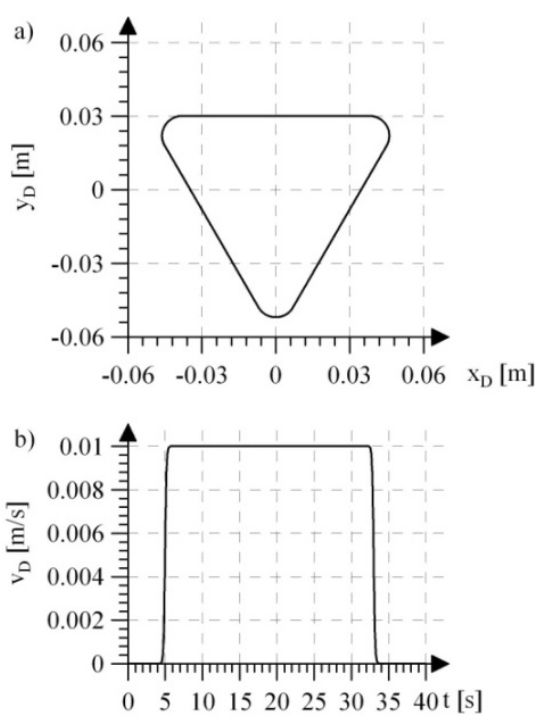

Rys. 5. a) tor ruchu, b) profil prędkości końcówki roboczej manipulatora

Fig. 5. a) path of motion, b) the velocity profile of the end effector of manipulator
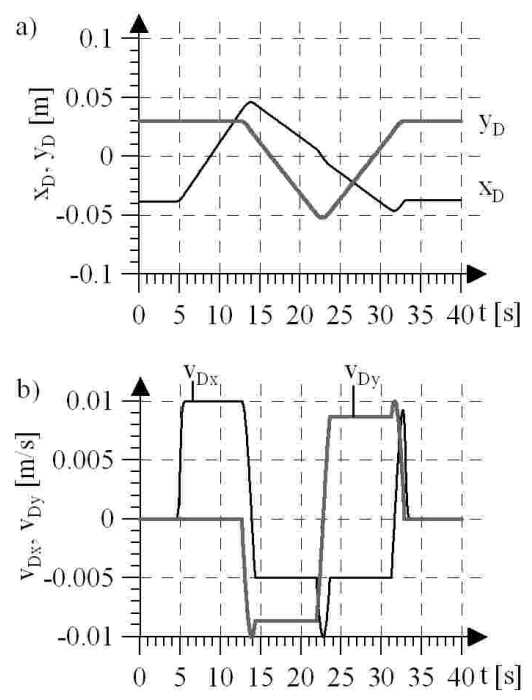

Rys. 6. Trajektoria pozycyjna: a) przemieszczenia końcówki roboczej, b) składowe prędkości końcówki

Fig. 6. Positional trajectory: a) displacements of the end effector, b) components of velocity

Wartość prędkości kątowej narzędzia $\omega=\omega_{C z}=\alpha_{2}$ przyjęto następująco (rys. 7):

$$
\omega=\frac{\omega_{\max }}{1+\exp \left[-c_{P}\left(t-t_{1}\right)\right]}-\frac{\omega_{\max }}{1+\exp \left[-c_{P}\left(t-t_{2}\right)\right]}
$$

gdzie: $\omega_{\max }=1500 \mathrm{rad} / \mathrm{s}$ - wartość prędkości kątowej narzędzia,

$c_{P}=101 / \mathrm{s}$ - współczynnik wpływający na długość fazy rozpędzania i hamowania,

$t_{1}=3 \mathrm{~s}$ - czas, w którym $\omega=\omega_{\max } / 2$ podczas fazy rozpędzania narzędzia, $t_{2}=35 \mathrm{~s}$ - czas, $\mathrm{w}$ którym $\omega=\omega_{\max } / 2$ podczas hamowania narzędzia, $t \in\langle 0,40\rangle \mathrm{s}$.

Wartość siły docisku narzędzia do obrabianej powierzchni wynika z przyjętych sztucznych więzów siłowych, czyli

$$
F=F_{C y}=\alpha_{3}
$$

Stanowi to trajektorię siłową przyjętą w postaci następującego równania (rys. 8) 


$$
F=\frac{F_{\max }}{1+\exp \left[-c_{F}\left(t-t_{1}\right)\right]}-\frac{F_{\max }}{1+\exp \left[-c_{F}\left(t-t_{2}\right)\right]}
$$

gdzie: $F_{\max }=10 \mathrm{~N}-$ wartość siły docisku,

$t_{1}=5 \mathrm{~s}$ - czas, w którym $F=F_{\max } / 2$ podczas fazy zwiększania docisku, $t_{2}=33 \mathrm{~s}$ - czas, w którym $F=F_{\max } / 2$ podczas zmniejszania docisku, $c_{F}=101 / \mathrm{s}$.

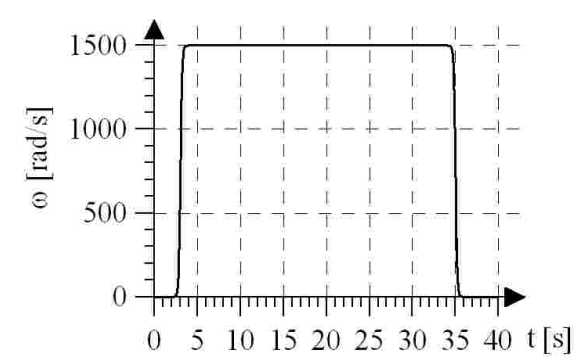

Rys. 7. Prędkość kątowa narzędzia

Fig. 7. The angular velocity of the tool

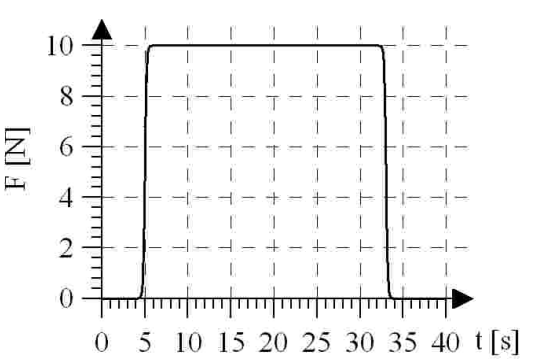

Rys. 8. Trajektoria siłowa

Fig. 8. Force trajectory

\section{Więzy manipulatora $w$ zadaniu wiercenia otworu}

W przypadku zadania wiercenia otworu zestaw więzów będzie taki jak na rys. 9. Zadanie określono względem układu więzów $\{c\}$ związanego z narzędziem i poruszającego się wraz z nim. W przypadku operacji wiertarskiej można zadać prędkość obrotową wiertła $\omega_{C z}=\alpha_{4}$ i prędkość jego posuwu $v_{C Z}=\alpha_{3}$. Ruchom tym towarzyszą na tyle duże siły interakcji, że trudno przyjąć uproszczenie polegające na ich pominięciu. Dlatego na rys. 8 podano również naturalne więzy siłowe występujące podczas procesu i są to: siła interakcji $F_{C z}=\alpha_{1}$ i moment interakcji $M_{C z}=\alpha_{2}$ na kierunku osi $c_{z}$. Prędkości oraz siły i momenty względem pozostałych osi powinny być zerowe, aby nie nastąpiło złamanie wiertła. Można również przyjąć inny, być może bardziej intuicyjny wariant więzów sztucznych, zadając siłę $F_{C z}=\alpha_{1}$ i rozumiejąc ją jako sztuczny więz siłowy. Wówczas prędkość $v_{C z}=\alpha_{3}$ będzie zaliczona do naturalnych więzów pozycyjnych i będzie funkcją siły $F_{C z}$ i właściwości materiału, w którym wykonywana jest operacja wiercenia. Podobnie można uczynić z parą więzów $M_{C z}=\alpha_{2}$ i $\omega_{C z}=\alpha_{4}$. Reasumując, można narzucić więzy pozycyjne, a siły interakcji nie będą sterowane, lub sterować siłami interakcji, a kinematyczne parametry procesu wiercenia będą ich funkcją. 


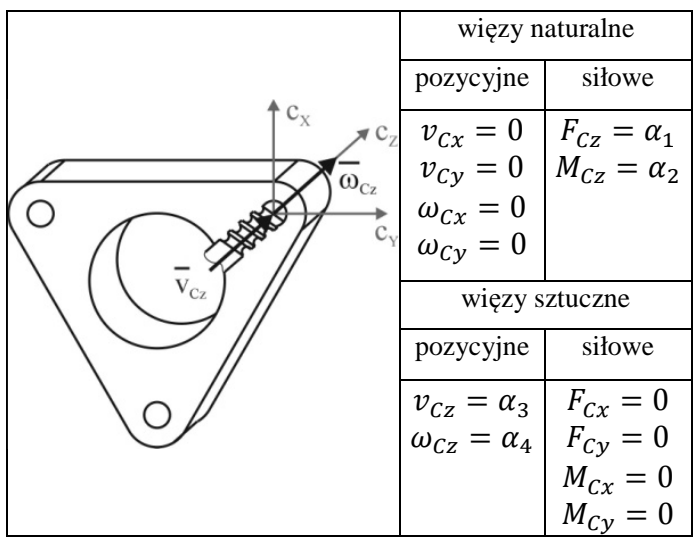

Rys. 9. Więzy naturalne i sztuczne w zadaniu wiercenia otworu

Fig. 9. Natural and artificial constraints in the task of hole drilling

Przyjmując pierwszy wariant więzów, podany na rys. 9, zadano przebiegi prędkości liniowej i kątowej wiertła. Wartość prędkości posuwu wiertła wynika z przyjętych sztucznych więzów pozycyjnych, czyli $v_{D}=v_{C Z}=\alpha_{3}$. Wartość prędkości $v_{D}$ przyjęto wg wzoru (13), gdzie założono $v_{D \max }=0.001 \mathrm{~m} / \mathrm{s}$ (rys. 10a). Wartość prędkości kątowej wiertła $\omega=\omega_{C Z}=\alpha_{4}$ przyjęto wg wzoru (14), gdzie założono $\omega_{\max }=50 \mathrm{rad} / \mathrm{s}$ (rys. 10b).
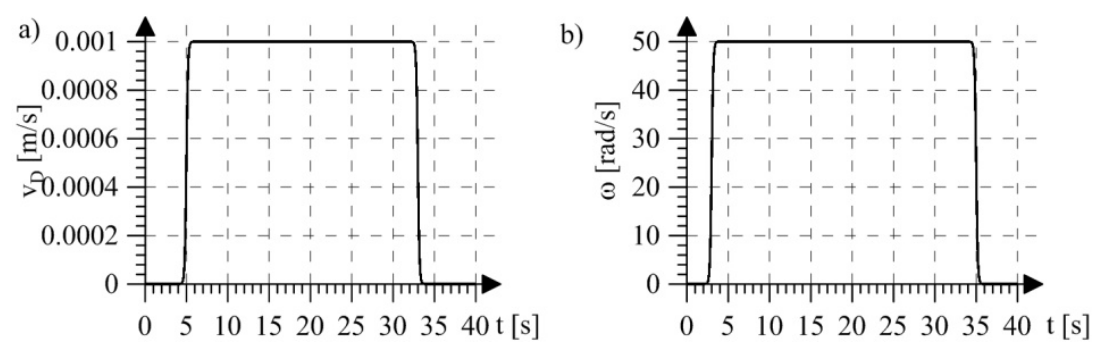

Rys. 10. Trajektoria pozycyjna końcówki roboczej w procesie wiercenia: a) prędkość posuwu wiertła, b) prędkość kątowa wiertła

Fig. 10. The positional trajectory of the end effector in the drilling process: a) the feed rate of the drill, b) the angular velocity of the drill

\section{Podsumowanie}

W wyniku analizy więzów końcówki roboczej manipulatora wynikających z założonego do realizacji zadania uzyskano trajektorię jej ruchu w przestrzeni roboczej. Tak zaplanowana trajektoria stanowi trajektorię zadaną układu sterowania i musi zostać zrealizowana w celu wykonania zadania. Realiza- 
cja wymienionych strategii obróbki krawędzi dyfuzora i wpływ wybranej strategii na jakość obróbki będą przedmiotem dalszych prac badawczych.

\section{Literatura}

[1] Blajer W.: Metody dynamiki układów wieloczłonowych, Monografie 35, Politechnika Radomska, Radom 1998.

[2] Burghardt A., Kurc K., Szybicki D.: Projekt zrobotyzowanego stanowiska z kontrolą siły, XIV Konf. Automatyzacji i Eksploatacji Systemów Sterowania i Łączności, ASMOR 2013, Jastrzębia Góra 2013.

[3] Burghardt A., Muszyńska M., Jagiełowicz-Ryznar C., Żylski W.: Aplikacja systemu wizyjnego do automatycznej adaptacji trajektorii narzędzia, XIV Konf. Automatyzacji i Eksploatacji Systemów Sterowania i Łączności, ASMOR 2013, Jastrzębia Góra 2013.

[4] Canudas de Wit C., Siciliano B., Bastin G.: Theory of Robot Control, Springer, London 1996.

[5] Craig J.J.: Wprowadzenie do robotyki, WNT, Warszawa 1995.

[6] Gierlak P.: Hybrid position/force control in robotised machining, Solid State Phenomena, 210 (2014) 192-199.

[7] Gierlak P.: Hybrid position/force control of the SCORBOT-ER 4pc manipulator with neural compensation of nonlinearities, in: L. Rutkowski et al. (eds.): ICAISC 2012, Part II, LNCS 7268, pp. 433-441, Springer-Verlag, Berlin, Heidelberg 2012.

[8] Gierlak P.: Model matematyczny kartezjańskiego manipulatora własnej konstrukcji, ZN PRz, Mechanika, 88 (2016) 115-125.

[9] Gierlak P.: Zastosowanie adaptacyjnego hybrydowego pozycyjno-siłowego sterowania manipulatorem w zrobotyzowanej obróbce mechanicznej, Modelowanie Inżynierskie, 15 (2013) 28-34.

[10] Gierlak P., Muszyńska M.: Inteligentne sterowanie ruchem robota manipulacyjnego z więzami geometrycznymi, Modelowanie Inżynierskie, 19 (2014) 19-24.

[11] Hendzel Z., Burghardt A., Gierlak P., Szuster M.: Conventional and fuzzy force control in robotised machining, Solid State Phenomena, 210 (2014) 178-185.

[12] Sabanović A, Ohnishi K.: Motion control systems, John Willey \& Sons (Asia) Pte Ltd., Singapore 2011.

[13] Spong M.W., Vidyasagar M.: Dynamika i sterowanie robotów, WNT, Warszawa 1997.

[14] Susłow G. K.: Mechanika teoretyczna, PWN, Warszawa 1960.

[15] Winiarski T., Zieliński C.: Podstawy sterowania siłowego w robotach, PAR, 12 (2008) 5-10.

[16] Yu F., Minami M., Maeba T., Yanou A.: Constraint-combined force/position hybrid control method with Lyapunov stability, Proc. SICE Annual Conference, 2011, pp. 671-676.

[17] http://www.ati-ia.com

[18] http://www.fanucrobotics.pl

[19] http://www.rad-ra.com 
[20] http://www.schunk.com

\section{THE MANIPULATOR CONSTRAINTS ANALYSIS IN THE TASK OF ROBOTISED MACHINING OF DIFFUSER}

\section{S u m m a r y}

This paper presents the analysis of the geometrical constraints of the robotic manipulator end effector, the task of which is the realisation of the diffuser machining. In terms of control theory, the realisation of this task is considered as a control of an object with partial movement restrictions. It requires determination of the desired trajectory of the robot's control system understood as so-called position and force trajectory. In this paper the geometry of the diffuser and the mathematical description of edges that will be deburred, are presented. The sets of natural and artificial, position and force constraints for this task and for task of hole drilling are given. The procedure of determining position and force trajectory which will be the reference trajectory of robot's control system is provided. The simulation results of generating robot's tip trajectory are presented.

Keywords: geometrical constraints, robotic manipulator, trajectory planning, robotized machining

DOI: $10.7862 / \mathrm{rm} .2016 .16$

Otrzymano/received: 14.09.2016 r.

Zaakceptowano/accepted: 28.09.2016 r. 